\title{
'N OORSIG OOR DIE NA-OORLOGSE TEOLOGIESE ONTWIKKELING IN DIE GEREFORMEERDE KERK IN SUID-AFRIKA (GKSA)
}

Dr. J. H. van Wyk

Wie hom besinnend besighou met die teologiese ontwikkeling in die GKSA na 1945 staan verbaas oor die hoeveelheid teologiese lektuur wat in hierdie tyd verskyn het. Ofskoon dit véél meer is as wat voorheen verskyn het, kan die stof tog nog min of meer oorsien en ook oorsigtelik aangebied word. Of daar werklik van teologiese ontwikkeling sprake kan wees, van uitbou en nuutbou, en of alles nie maar blote restourasie en herhaling was van wat in Nederland - en Duitsland - reeds gesê is nie, is natuurlik 'n ander vraag. Miskien kan hierdie vraag voorlopig sò beantwoord word deur te stel dat daar plek-plek op die teologiese veld nuutbou was maar dat, wat die geheel betref, in hoofsaak aangesluit is by veral Nederland.

Wat hier volg, maak nie aanspraak op volledigheid nie. Dit is byvoorbeeld onmoontlik om binne die bestek van een artikel te verwys na alle meestergraad-werk asook alle teologiese artikels, ten opsigte waarvan die teologiese blad In die Skriflig sedert 1966 'n groot bydrae gelewer het. Aan die ander kant sal weer verwys word na teologies-georiënteerde werke van nie-teoloë en selfs ook na nieteologiese werk van teoloë. Ek meld ook dat nie alle aangehaalde werke ewe indringend bestudeer is nie.

Met hierdie artikel betree ek in 'n baie groot mate nuwe terrein. Daar bestaan wel 'n uitstekende oorsigtelike artikel van J. Chr. Coetzee oor Die Skriftelike Getuienis uit die Gereformeerde Kerk ('). Die artikel gaan, uiteraard, net tot 1959 . Daarby volg die skrywer, as opvoedkundige, 'n nie-teologiese indeling van die stof terwyl ook meer histories-reflekterend as teologies-evaluerend aangebied word. Nietemin is dit ' $n$ baie waardevolle artikel.

Ek volg meer 'n teologiese indeling en wel volgens die bekende ensiklopediese benadering, uiteraard met aanpassings hier en daar. Dit bring mee dat die teologiese ontwikkeling agtereenvolgens nagegaan word in die bibliologiese, ekklesiologiese, dogmatologiese, diakonologiese en missiologiese vakke.

\section{BIBLIOLOGIESE BESINNING}

Ten opsigte van die tekskritiek, algemene en besondere kanoniek asook hermeneutiek, bestaan daar 'n aantal bronne wat van direkte en indirekte betekenis vir hierdie vakgeb!ed is. Ek dink hier aan $\mathbf{S}$. J. du Plessis se Jesus en die kanon van die Ou Testament ${ }^{(2)}$, F. N. Lion-Cachet se kanoniese studie oor die inlejdingsformule van die dekaloog $\left({ }^{3}\right)$, J. C. Coetzee se gids deur die boeke van die Nuwe Testament ( ${ }^{4}$ ) en sy Pleidooi vir vernuwing in die besondere kanoniek

Hierdie artikel is in Augustus 1978 opgestel met die oog op die kerkhistoriese Werkgemeenskap. 1979. 
$\left.{ }^{5}\right)$. Hiernaas kan verwys word na nog 'n groep studiewerke, bv F. H. van Rooy oor staatsverdrae ( $\left.{ }^{6}\right)$ en J. Postma oor die hyperbaton ( ${ }^{7}$ ) én nog ander $\left({ }^{8}\right)$ van meer indirekte betekenis hier.

Wat die Bybelse argeologie en kultuurhistoriese agtergrond betref besit ons twee mooi omvattende studies, nl. S. du Toit se Ou Testament en Ou Ooste ( ${ }^{\circ}$ ) en S. C. W. Duvenage se Die Dekor van die Nuwe Testament $\left({ }^{10}\right)$.

Op die gebied van die eksegese is werklik baie min gelewer. Volgens my kennis is daar net die een kommentaar van P. J. S. de Klerk oor Hebreërs ("I) en die twee - deeglike - kommentare van J. H. Kroeze oor Job ( ${ }^{12}$ ) en Josua $\left({ }^{13}\right)$.

Kyk ons na die werk op die gebied van die Ou Testamentiese en Nuwe Testamentiese openbaringsgeskiedenis, dan verander die prent aanmerklik.

Wat die Ou Testament betref, bestaan daar die populêre werk van Kroeze, Handboek Bybelse Geskiedenis $\left({ }^{14}\right)$. In besonder moet hier egter melding gemaak word van die baanbrekerswerk op hierdie gebied deur S. du Toit, veral met sy Openbaringsgeskiedenis van die Ou Testament $\left({ }^{15}\right)$, uitgewerk rondom die sentrale tema van die Koninkryk van God. Hierby kan ook 'n aantal ander belangrike geskrifte van Du Toit genoem word $\left({ }^{16}\right)$. Op hierdie werk het die opvolger van S. du Toit, nl. J. L. Helberg, voortgebou met sy Openbaringsgeskiedenis van die Ou Testament $\left({ }^{17}\right)$ en ander geskrifte $\left({ }^{18}\right)$. Hierby moet ook verwys word na die studies van P. J. S. de Klerk ( $\left.{ }^{19}\right)$, J. H. Kroeze $\left({ }^{20}\right)$ en F. N. Lion-Cachet ( ${ }^{21}$ ).

Ek wil hier graag 'n paar woorde se̊ oor die werk van $\mathbf{S}$. du Toit. Sy betekenis is veral daarin geleë dat hy sy studente geleer het om breed te werk en om wyd kennis te neem van alle standpunte. Wie nie alle argumente behoorlik afweeg nie, is onwetenskaplik besig. Terselfdertyd was hierdie omvattende aanpak by Du Toit self ' $n$ leemte omdat dit maklik aanleiding gebied het tot wydlopighe'd en vaagheid oor eie standpunt. Belangrik was verder sy worsteling om 'n suiwere interpretasie van die oergeskiedenis te vind en sy afwysing van die ewolusionjsme (ofskoon nie van die ewolusie-gedagte nie). Sy beklemtoning van die belangrikheid van goeie kennis van die Umwelt van die Ou Testament vir die prediking, 'n saak waarmee hy hom jare besig gehou het en wat ook in 'n omvattende geskrif sy neerslag gevind het, verdien besondere vermelding. Hy was die eerste persoon in die GKSA wat behoorlik begin bou het aan die Outestamentologie.

Die besonder groot en gehaltevolle bydrae wat die Nederlandse Suid-Afrikaner J. H. Kroeze gelewer het tot die uitbou van die Outestamentologie. Eervolle vermelding verdien ook eervolle vermelding.

Kyk ons na die Nuwe Testament, dan is hier ook mooi werk gelewer. Ofskoon hy nie veel groot werke geskryf het nie, is die fondamente vir die Nuwetestamentologie tog deeglik gelê deur W. J. Snyman. Sy oud-studente het die waarde van hierdie werk begryp en sy belangrikste artikels saamgebundel en uitgegee onder die titel Nuwe 
en Ou Dinge (22). Sy toekomstige opvolger, Tjaart van der Walt, promoveer in 1962 in Nederland onder leiding van H. N. Ridderbos op 'n skitterende proefskrif te wete Die Koninkryk van God - Naby! ${ }^{23}$ ), 'n proefskrif wat onmiddellik na sy verskyning in Nederland in 1962 nie die besondere aandag gekry het wat dit verdien het nie omdat alle konsentrasie toe gerig was op die verskyning van twee ander opspraakwekkende proefskrifte nl. G. Th. Rothuizen se Primus Usus Legis en H. M. Kuitert se De mensvormigheid Gods van dieselfde jaar. Van der Walt sou later voortbou op die begonne weg met sy Openbaringsgeskiedenis ${ }^{24}$ ). Dit is myns insiens een van die grootste teologiese tragedies dat hierdie talentvolle akademikus - vanweë sy aanstelling as rektor van die PU vir $\mathrm{CHO}$ - vir die teologiese wetenskap verlore is. Tog beteken dit nie dat hiermee 'n onopvulbare leemte ontstaan het nie, want in 1965 promoveer J. C. Coetzee op Volken Godsvolk in die Nuve Testament ${ }^{25}$ ) en in 1969 L. Floor op De nieuwe exodus $\left.{ }^{26}\right)$. Trouens, laasgenoemde het al deur middel van 'n hele aantal studies 'n mooi bydrae gelewer tot die Nuwetestamentologie $\left({ }^{27}\right)$.

Ten opsigte van die Nuwe Testament, kan ook nog verwys word na twee stuoiies uit die vyftigs, van J. A. Schutte ${ }^{\left({ }^{28}\right)}$ en W. J. van der Merwe $\left({ }^{29}\right)$, ook na een van P. J. S. de Klerk $\left({ }^{30}\right)$ en veral die versamelwerk Die Koninkryk van God ( ${ }^{31}$ (wat ook Ou Testamentiese en ander opstelle bevat).

Ook hier wil ek 'n paar woorde sê oor die werk van W. J. Snyman. Ek sou sy werk wou saamvat onder die volgende hoofde: die allesomvattende betekenis van die woord ,kerk" in sy plaaslike en universele strekking; die noodsaaklikheid van die ware ekumene; die honorering, maar ook relativering, van die begrip „volk" of "nasie" (wat in sy gelowiges gered word); man van die „derde weg" (bv. nie kleur- of kleurlose teologie nie, maar kleurryke teologie); diepgrawer, maar juis daarom trae publisis. Dit is opvallend dat een van die belangrikste besluite (m.i. dié belangrikste) wat hierdie eeu deur 'n sinode van die GKSA geneem is $1955 / 1961$ ), naamlik dié in verband met organisatoriese kerkeenheid van die Gereformeerde kerkgroepe uit die verskillende volksgroepe, geinisieer is deur die Nuwestestamentikus W. J. Snyman - en nie, soos verwag sou kon word, deur 'n kerkregkundige nie.

\section{EKKLESIOLOGIESE EKSPOSES}

In die GKSA is steeds 'n besondere aksent gelê op die waarde en betekenis van die kerkreg en kerkregering en inderdaad is daar reeds van heel vroeg af $\left({ }^{32}\right)$ intensiewe aandag hieraan bestee. Belangrik is in hierdie verband die twee verskene proefskrifte, van G. P. L. van der Linde oor Die Grondbeginsels van die Presbiteriale Kerkregeringstelsel $\left.{ }^{(33}\right)$, waaroor wisselende waardering uitgespreek is $\left({ }^{34}\right)$, en dié van $\mathrm{J}$. J. van der Walt oor Christus as die Hoof van die Kerk ( $\left.{ }^{35}\right)$. Besonder belangrik was ook die verskyning van die Handleiding by die Kerkorde ( ${ }^{36}$ ) deur ' $n$ hele aantal skrywers maar met B. Spoelstra duidelik as die belangrikste eksponent. Hierdie 
werk is te meer belangrik omdat dit na my wete die enigste van sy soort in Suid-Afrika is $\left.{ }^{37}\right)$. Daarby is dit helder en duidelik geskrywe met voortdurende aansluiting by die Skrifgegewens - waarmee natuurlik nie beweer is dat die boek foutloos is nie $\left({ }^{38}\right)$.

Hiernaas het daar ook kleiner geskrifte oor die kerkreg verskyn $\left({ }^{39}\right)$. Die GKSA is in die vorige eeu uit stryd gebore en daar kon dus verwag word dat kerkgeskiedenis besondere aandag sou opeis. Inderdaad was dit ook die geval $\left({ }^{40}\right)$. Baanbrekerswerk is op hierdie gebied gedoen deur J. P. Jooste deur middel van etlike boeke en talle gemeentegeskiedenisse in gedenkboeke $\left({ }^{41}\right)$. Besondere vermelding verdien hier sy proefskrif oor Die Verhouding tussen Kerk en Staat $\left({ }^{42}\right)$. sy groot werk oor Die Geskiedenis van die Gereformeerde Kerk in Suid-Afrika (43), 'n werk wat veral uitmunt in die representasie in plaas van interprestasie van die feite, en sy Gedenkboek van die Dorslandtrek $\left(^{44}\right)$. Jootse se opvolger, G. C. P. van der Vyver, het ook 'n mooi kerkhistoriese bydrae gelewer met sy skitterende boek oor Professor Dirk Postma $\left({ }^{45}\right)$ en sv Mu erfenis is vir mu mooi ${ }^{(46)}$, waarin hy die geskietenis van die Teologiese Skool on Potchefstroom en die PU vir CHO beskryf. Nuwe lig op die Gereformeerdes in Suid-Afrika bied B. Spoelstra, ons veelsydigste ekklesioloog, met sy deeglike werk oor Die „Doppers” in Suid-Afrika ( $\left.{ }^{47}\right)$. Maar h'ermee het ek nagelaat om te verwys na die heel eerste werk oor Die Ontstaan van die Gereformeerde Kerk in Suid-Afrika (1957) deur B. R. Krüger ${ }^{\left({ }^{4}\right)}$, 'n work wat getipeer is as .,breetgestelde, intens ondersoekte en streng gedokumenteerde proefskrif" $\left({ }^{49}\right)$, maar vir my aanvoeling in die GKSA nie baje hoog aangeskrvf staan nie, iets wat moontlik saamhang met die toekenning van die D-graad deur die $\mathrm{UP}$ in plaas van die PU vir $\mathrm{CHO}$.

Besonder belangrik is ook die twee geskrifte wat rondom die eeufees van die GKSA in 1959 uitgegee is nl. Die Gereformeerde Kerk in Suid-Afrika 1859 - 1959 ( $\left.{ }^{50}\right)$ en Eeufees te Rustenburg ( $\left.{ }^{51}\right)$. Hiermee saam kan ook genoem word die talle gemeentelike eeufees- of halfeeufees-geskrifte, te veel om hier op te noem ( ${ }^{52}$ ).

Ek verwys hier ten slotte na $M$. J. Badenhorst se studie oor die kruisdoppers ( ${ }^{53}$ ) en V. E. d'Assonville s'n oor Totius ( $\left.{ }^{54}\right)$. Soos bekend, is lg skrywer besig met 'n omvattender werk oor Totius.

Ek sluit hierdie stuk oor die ekklesiologiese studies af deur te verwvs na ekumeniek. Naas die belangrike werk wat Snyman - en ook Totius - op hierdie terrein gelewer het, kan spesifiek verwys word na die bydrae van B. Duvenage met sy studie oor die Wêreldraad van Kerke $\left({ }^{55}\right)$, asook dié van J. M. Vorster ${ }^{(56)}$. Pertinent is die saak ook aan die orde gestel deur P. J. Pelser in sy dogmatiese werk oor Die roeping tot sigbaarmaking $\left({ }^{57}\right)$.

Dit is ook belangrik om hier te wys op die interkerklike gesprek wat die Geref. Kerk Johannesburg-Sentraal met die NG Kerk Johannesburg (en later NGK Johannesburg-Oos) vanaf 1964-1970 gevoer het toe hierdie kontak van sinodeweë op 'n m.i. sinodokratiese wyse beëindig is. Gedurende hierdie periode is 'n blad, Kruispunte, gepu- 
bliseer. (Daar kon nie geslaag word om die Ned. Hervormde Kerk te betrek nie).

\section{DOGMATOLOGIESE WERKE}

Indien daar enigsins 'n vergelyking getref moet word tussen die hoeveelheid werk wat daar op dogmatologiese gebied en al die ander vakgebiede gelewer is, dan staan e.g. gebied ver vooraan. Trouens, mens sou met 'n bietjie oordrywing kon beweer dat daar op dogmatologiese gebied net so veel gelewer is as op àl die ander gebiede saam.

Ek skryf hier eers oor die simboliek, dogmageskiedenis, polemiek en apologetiek, om daarna meer aandag te gee aan die dogmatiek en etiek.

Wat die simboliek betref, is daar die boek van P. J. S. de Klerk oor Gereformeerde Simboliek ${ }^{(58)}$, 'n handige werk, maar vanweë sy kompilatoriese opset ook 'n werk met mankemente.

Dogmageskiedenis was vir 'n lang tyd 'n afgeskeepte terrein, volkome ten onregte, hoewel daar in die jongste tyd 'n groter konsentrasie hierop merkbaar is. L. F. Schultze se Geloof deur die eeue, wat op die oomblik nog in die pers is, sal eersdaags verskyn en behoort 'n baie groot leemte te vul. Raakvlakke met die dogmageskiedenis, besit ook die groot werk van B. J. van der Walt oor die natuurlike teologie ( ${ }^{59}$ ) en dié van C. J. Malan oor Ambrosius ( ${ }^{60}$ ).

Geskrifte oor polemiek-apologetiek is volop. Twee filosofiese studies in die veertigerjare verdien hier vermelding, dié van J. M. de Wet $\left(^{\left({ }^{1}\right)}\right.$ en P. J. Coetzee ( $\left.{ }^{62}\right)$. Ons eerste polemiese geskrif, geskryf deur 'n aantal predikante, verskyn in 1945 en heet Waarheid en Dwaling $\left({ }^{63}\right)$. Ons eerste polemikus en apologeet was egter, kragtens sy opdrag as teologiese professor, B. J. de Klerk. Hy wys op die tendense in die moderne wysbegeerte en teologie ( ${ }^{64}$ ) en waarsku teen die Roomse gevaar $\left({ }^{65}\right)$. Ons veelsydigste vakman op hierdie gebied is egter S. P. van der Walt. Sy werk oor Die Wysbegeerte van Dr. Herman Bavinck (66), 'n werk wat R. H. Bremmer as "verdienstelijk" getipeer het $\left({ }^{67}\right)$, het hom die nodige fundering vir hierdie taak verskaf, waarop hy, vanaf sy ampsaanvaarding ${ }^{\left({ }^{68}\right)}$. voortwerk tot die verskyning van sy groter werk op hierdie terrein nl. Dwaling en Waarheid ( $\left.{ }^{69}\right)$.

Hiermee is natuurlik nog nie naaste by alles vermeld nie. Ons sou ook nog kon verwys na $D$. Kempff se twee publikasies oor Rotary ( ${ }^{70}$ ) en Geloofsgenesing (1) asook na L. S. Kruger se brosjure oor die AGS ( ${ }^{72}$ ). Dit is haas onmoontlik om hier ook maar enigsins te probeer om alle kleiner polemiese geskrifte te noem - maar ek verwys daarna in die verbygaan.

Tog moet ek die polemiese geskrif van L. S. Kruger oor Waarom is $u$ lid van Die Gereformeerde Kerk? ( $\left.{ }^{3}\right)$ hier noem, 'n geskrif wat helaas mank gaan aan eensydighede, veralgemenings en vertekeninge.

Hierby sou ek ook graag 'n hele reeks werke wou noem wat op 
hierdie terrein hulpwerk verrig, soos bv Roeping en Werklikheid

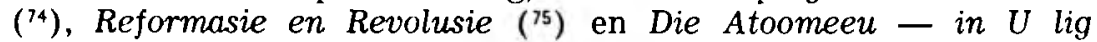
( $\left.{ }^{76}\right)$. Verder kan verwys word na die hulpdiens wat die filosofiese geskrifte van H. G. Stoker $\left({ }^{77}\right)$ en J. A. L. Taljaard $\left({ }^{78}\right)$ hier bied.

En nou die spesifiek dogmatiese geskrifte, wat ek rofweg volgens die verskillende loci in die dogmatiek aan die orde stel.

Die GKSA staan gewoonlik bekend as „dogmaties”, en tog staan ons voor die betreurenswaardige feit dat - anders as dje GKN nog geeneen van ons eie dogmatici dit gewaag het aan 'n omvattende dogmatiek nie. En dit geld selfs vir alle dogmatici uit die 3 Afrikaanse Kerke! Ons staan voor die verstommende feit dat die eerste dogmatiek in Afrikaans deur 'n Lutheraan geskryf is $\left({ }^{79}\right)$. Ons dog. matici het wel, nog gedurende die corlogsjare (1942), 'n soort populêre dogmatiek laat verskyn nl. Kosbare Goud $\left(^{80}\right)$, maar teologieswetenskaplik was dit van mindere betekenis. Weliswaar het S. J. van der Walt ' $n$ beknopte en populêre dogmatiek gelewer ( $\left.{ }^{81}\right)$, maar die doel was beperk: 'n handboek vir onderwysers met die oog op Bybelkunde. Baie beteken'svol is m.i. die verkorte heruitgawe van Calvvn se Institusie deur A. Duvenage ${ }^{\left({ }^{82}\right)}$. Vermelding verdien ook V. E. d'Assonville se John Knox and the Institutes of Calvin ( $\left.{ }^{83}\right)$.

Ons eerste dogmatikus van naam was J. D. du Toit, maar sy betrokkenheid by o.a. die Bybelvertaling en Psalmberyming en die feit dat hy soms nagenoeg alle teologiese vakke moes doseer, het meegebring dat sy dogmatiese werk, ofskoon belangrik, tog 'n torso gebly het $\left(^{84}\right)$. P. J. S. de Klerk het in hoofsaak Kuyper - onveranderd aangebied terwyl $\mathbf{S}$. J. van der Walt veel meer op voetspoor van die altyd aktuele Bavinck ${ }^{85}$ ) voortgewerk het. Ons veelsydigste dogmatikus tot sover was sonder twyfel S. C. W. Duvenage, soos blyk uit die kwantiteit en kwaliteit van sy gelewerde publikasies.

Wat die Godsleer betref, het daar, sover ek weet, geen belang. rike werk verskyn n'e. I. D. Kruger skryf 'n kleiner geskrif oor God se Voorsienigheid ${ }^{86}$ ).

Aangaande die skeppingsleer kan verwys word na D. Kempff se

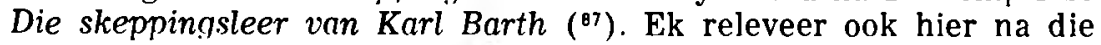
reeds vermelde Ou Testamentiese studies van $\mathrm{S}$. du Toit in verband met skepping en ewolusie asook na ander kleiner - polemiese geskrifte wat veral gerig is teen die ewolusionisme $\left({ }^{88}\right)$.

Reeds geruime tyd voordat die Koninkryk tot so 'n belangrike teologiese tema verhef is, het K. S. van Wyk de Vries geskryf oor

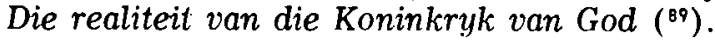

Kyk ons na die Christologie, kan verwys word na die mooi dogmatiesetiese studie van S. C. W. Duvenage oor Die Navolging van Christus $\left({ }^{90}\right)$. C. J. Malan het ook 'n waardevolle bydrae gelewer met sy opsommings van boeke wat handel oor die Soteriologie by Calvyn (').

Miskien moet ons ook hiér, in aansluiting by die Christologie, verwys na 'n reeks geskrifte wat oor die uitverkiesing en bekering handel. Ek dink hier veral aan L. F. Schulze se Calvin's reply to 
Pighius ( ${ }^{92}$ ), die boek ,Revival” of Reformasie? ( ${ }^{93}$ ), wat baie nou aansluit by J. D. du Toit se gedeë werk oor Het Methodisme van 1903, asook P. J. Coetzee se Uitverkiesing en bekering $\left({ }^{94}\right)$. Opvallend op dogmatiese terrein is telkens weer die noue aansluiting by Calvyn.

Opvallend is eweneens die volkome gebrek aan 'n groot studie oor die pneumatologie, hoewel ek graag verwys na C. Hattingh se Die Kerk en die Heilige Gees ( $\left.{ }^{95}\right)$.

Daarmee is ons by die ekklesiologie waar die oes belowender is. P. J. S. de Klerk besin veral oor kerk en verbond $\left({ }^{96}\right)$, terwyl P. W. Buys ' $n$ deeglike stuk werk lewer, in lyn met Kuyper, oor die kerk as organisme en instituut $\left({ }^{97}\right)$, 'n onderskeiding wat in die teologie egter hoe langer hoe minder gebruik word en meer en meer vervang word deur die onderskeiding kerk en Koninkryk. S. C. W. Duvenage besin oor Die Verhouding van Kerk tot Volk $\left({ }^{98}\right)$ - en ek verwys hier ook graag na die reeds vermelde Nuwe Testamentiese studies van $W$. J. Snyman op hierdie gebjed. P. J. Pelser attendeer op Die roeping tot sigbaarmaking van die katolisiteit van die kerk en ook hier noem ek weer B. Duvenage se boek oor die WRK.

Ek bring hier - by die ekklesiologie - ook die Skrifleer ter sprake, iets wat in die dogmatiek gewoonlik voorop gaan, maar m.i. logies hier tuishoort, saam met die sakramentologie. Die GKSA staan bekend as ' $n$ kerk wat 'n deurslaggewente beklemtoning plaas op die Woord van God en inderdaad is daar ' $n$ ryk oes aan doomatiese studies oor Skrif en openbaring. Die stroom begin reeds in 1937 met B. J. de Klerk se Vorme en karakter van Biblisisme $\left({ }^{99}\right)$, daarna volg $\mathrm{S}$ J. van der Walt se Die Gorsopenbaring in die teologie van Karl Barth $\left({ }^{100}\right)$ en dan J. D. du Toit se Die Bybel is die Woord van God (101). Dan volg S. C. W. Duvenage se uitstekende geskrif oor Die Gesag van die Heilige Skrif $\left({ }^{102}\right)$, waarin hy daarvan afsien om op skolastiese wyse met ' $n$ formele opvatting, afges'en van die inhoud van die Skrif, te opereer. Hy sluit hier nou aan by Berkouwer, van wie se teologiese werk Totius vanuit die staanspoor besonder hoë verwagtinge gekoester het $\left.{ }^{103}\right)$. Ook C. F. C. Coetzee gee aandag aan Die scopus van die Skrif by Calvyn (104). F. W. Buytendach gaan breedvoerig in op die vorm-inhoud-problematiek $\left({ }^{105}\right)$, met skerp kritiek op talle Nederlandse teoloë, oa G. C. Berkouwer. Meer waarderend t.o.v. Berkouwer skryf $\mathrm{H}$. Denkema in sy De betroubare Woord $\left({ }^{106}\right)$, waarin hy selfs van „oneffenhede" in die Bybel meen te praat.

Ek kon geen werk oor die sakramentologie opspoor nie. Ook nie oor die konfessiologie nie, hoewel dit bekend is dat $\mathrm{H}$. Dijkstra hom hiermee besig hou $\left({ }^{107}\right)$.

Ten opsigte van die eskatologie is die oes ook besonder skraal. $\mathrm{Ek}$ verwys slegs na $\mathrm{J}$. W. Jansen van Ryssen se Die Messias uit die aarde $\left(^{108}\right)$, 'n werk wat in die lig van A. König se studies oor die Antichris $\left({ }^{109}\right)$ op bepaalde punte agterhaal is. Die boek adem oor die algemeen die gees van 'n pessimistiese ondergangstemming - dikwels tipies van die Gereformeerde teologie in die algemeen - soos blyk uit die opmerking dat dit vyf minute voor twaalf (middernag) is. Heel anders, en meer in die gees van die triomf van die genade, 
byma in die sin van 'n triomfalistiese teologie, skryf Tjaart van der Walt: „Daarom kan dit ook nie so voorgestel word asof die toekoms al hoe donkerder word nie: die Bybelse toekomsverwagting is geen evolusie-in-trurat nie... Die donkerste uur in die wereldgeskiedenis is agter die rug - toe God dit helder oordag van middendag tot middernag laat word het (Mark $15: 33$ par.). Daarom is voor ons nie 'n wereldnag nie maar die aanbreek van 'n nuwe dag - God se dag. ' $n$ Soort gelate ondergangstemming betaam dan ook die Christelike toekomsverwagting allermins: in Christus is ons méer as oorwinnaars ... (Rom. : 35 e.v.)... En nou word dit nie al hoe donkerder nie maar al hoe ligter: ,Die nag het ver gevorder, en dit is amper dag' (Rom. $13: 12$ )" $\left({ }^{110}\right)$. Ek verwys ook tussen hakies na C. W. M. du Toit se Toekomstige Wêreldgebeure (iii) met sy chiliastiese strekking.

Hiermee neem ek afskeid van die dogmatiek en begeef my op ietwat meer bekende terrein naamlik die etiek. Vir baie jare was etiek eintlik die stiefkind in die teologie terwyl dit vandag, veral vanweë die talle moderne vraagstukke wat om antwoorde roep, 'n ongekende bloeiperiode beleef.

Wat die prinsipiële etiek betref, het ons veelsydigste etikus, B. Duvenage, 'n stewige bydrae gelewer met 'n hele reeks artikels (112). Met sy Beroepsarbeid in die lig van die Gereformeerde Etiek (113)) lewer hy ook ons eerste etiese werk. Goeie werk het ook S. P. van der Walt gedoen en veral bekend is sy Gods wet en "die ander wet" (14). P. W. Buys vestig die aandag op Die botsing van pligte as etiese vraagstuk (115). Die filosowe H. G. Stoker en P. G. W. du Plessis het ook met hulle werke oor Die Grond van die sedelike (116) en Opskorting van die etiese? (117), onderskeidelik, belangrike hulpdiens verrig.

In sy Bewaar jou goeie pand $\left(^{118}\right)$ het $\mathrm{P}$. J. de Bruyn 'n aantal etiese onderwerpe aangesny, terwyl ekself probeer het om in my Etiek in ' $n$ eeu van tegnologie en tegnokrasie (119) 'n paar etiese temas behoorlik op tafel te kry.

Hoewel die oes op die gebied van mediese etiek besonder skraal is, is daar weer 'n hele aantal boeke geskryf oor die seksuele etiek. Ek dink hier o.a. Die Selfmoord van ' $n$ nasie $\left({ }^{120}\right)$, wat oor geboortebeperking handel maar ' $n$ boek wat hopeloos verouderd is, verder Die heilige huwelik (121) en ook J. H. Kroeze se prikkelende en verruimende boek Bybel en Seks (122). Besonder verdienstelike werk is op hierdie terrein gelewer deur P. J. de Bruyn met sy Die Christen en Geboortereëling (123) waarin hy op verantwoorde wyse sterk aansluit by Nederlandse besinning op dié terrein ( ${ }^{124}$ ), en Kuisheid vór die huwelik $\left({ }^{125}\right)$, waarin hy nié die weg van Nederland volg nie. Melding kan ook hier gemaak word van sy - breër opgesette - studie oor die etiek van Kuitert ( $\left.{ }^{126}\right)$.

Ekself het 'n bydrae probeer lewer op die terrein van die politieke etiek met 'n bespreking van die oorlogsvraagstuk in Etiek van Vrede ( $\left.{ }^{127}\right)$, opgevolg met 'n aantal artikels oor diverse polities-etiese vraagstukke $\left({ }^{128}\right)$. Teoloë in die GKSA het hulle besonder lank en indringend hesig gehou met die rasse- of volkereproblematiek, 'n 
saak wat weliswaar nie altyd vanuit 'n spesifiek etiese hoek benader is nie maar tog 'n duidelike etiese dimensie vertoon - vandaar dat ek dit hier noem. Hieroor het 'n stroom van lektuur verskyn $\left({ }^{129}\right)$. Die groot leemte in hierdie origens deeglike prinsipiële studies is dat te weinig konkreet rekening gehou is met die immense problematiek en verweefdheid van die Suid-Afrikaanse volkere-situasie, met ander woorde daar is in die studies nie 'n duidelike korrelasie tussen ideaal en werklikheid, beginsel en praktyk nie. Daar is 'n groot gebrek aan verantwoordelike situasie-etiek.

Ten slotte kan ook nog verwys word na hulpstudies oor persetiek ${ }^{\left({ }^{130}\right)}$ en arbeidsetiek ( $\left.{ }^{131}\right)$.

Hiermee is in voëlvlug die dogmatologiese arbeid oorskou en ek wend my vervolgens na die volgende terrein.

\section{DIAKONOLOGIESE STUDIES}

Wanneer ons 'n blik werp oor die diakonologiese studies blyk al gou dat daar in sommige vakke besonder goeie werk gelewer is terwyl daar in ander vakke groot brak kolle voorkom. Laat mv begin om te verwys na die boek Wending? (132) van ons vrugbaarste diakonoloog. W. J. de Klerk. Hierdie boek, wat natuurlik méér bevat as blote diakonologie, is vir my gevoel in die GKSA taamlik doodgeswyg en tog was dit 'n werk wat as't ware 'n nuwe tydvak ingelui het. Jonger predikante het na die boek gegryp omdat dit hulle gehelp het om dikwels verroeste situasies te deurbreek. Daarby is die inhoud kunstig verwoord en prinsipieel deurdink - waarmee weer nie gesê, is dat die boek sonder foute is nie.

Ek wend $\mathrm{my}$ vervolgens na die spesifieke diakonologiese vakke en begin by homiletiek. Op hierdie terrein het V. E. d'Assonville mooi werk gelewer, eers met sy Kerk en Prediking ( ${ }^{133}$ ), later omgewerk en uitgebou tot Die dwaasheid om te preek (134). Hierdie wetenskaplike werk het hy aangevul deur die uitgee van preekbundels, iets wat op die oomblik in toenemende getalle verskyn en wat hier, saam met dagboeke $\left.{ }^{135}\right)$, slegs deur my in die verbygaan vermeld word omdat dit te veel is om op te noem (136). Ek verwys ook in hierdie verband na homiletiese Skrifstudies soos dié van S. C. W. Duvenage oor die Bergpredikasie $\left({ }^{137}\right)$ en die reeks van J. H. Kroeze oor Hooglied, Hiskia, Saul, Tuin van Eeden, Jeremia, Adam en Eva en prediker ( $\left.{ }^{138}\right)$.

Ten opsigte van die liturgie kan verwys word na J. P. Jooste se Kom in sy voorhowe $\left({ }^{139}\right), \mathrm{P}$. J. de Bruyn se Aktiewe Kerkgangers $\left({ }^{140}\right)$ en D. C. S. van der Merwe se vraag na liturgiese vernuwing (141). Laasgenoemde stel ook die vraag na 'n veel hoër frekwensie van nagmaalviering gewetensvol aan die orde $\left.\left({ }^{142}\right)\right)$. M. A. Kruger besin oor Wat moet ons sing in godsdiens en erediens? (143) terwyl die musiko loog J. J. A. van der Walt skryf oor Die Afrikaanse psalmmelodië̈ (144). D. Kempff oordeel dat erediens en kollekte wesentlik bymekaar hoort ( $\left.{ }^{145}\right)$.

Op die gebied van die Kategetiek is goeie werk gelewer. Die GKSA het altyd 'n ope oog gehad vir jeugwerk, tot in sy wydste ver- 
band van CNO (146). C. J. H. de Wet en J. Chr. Coetzee lewer fundamentele werk met hulle besinning rondom die kategese $\left({ }^{147}\right)$. Dit word mooi aangevul deur J. P. Jooste se Studiegids vir Kategetiek ${ }^{(148)}$ en die pedagoog $\mathrm{J}$. $\mathrm{H}$. van Wyk se metodiese riglyne vir kategetiese onderrig $\left({ }^{149}\right)$, terwyl ek ook terloops verwys na laasgenoemde se breed opgesette werk Eksistensieteologie en Godsdiensonderrig

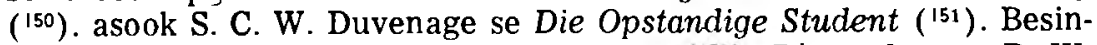
nende jeuglektuur ontbreek ook geensins $\left({ }^{152}\right)$. Die pedagoog $\mathrm{P}$. W. Bingle lewer ' $n$ belangrike bydrae oor Die Gereformeerde Kerk en die onderwys in Suid-Afrika 1859 - 1959 ( ${ }^{(53)}$.

Ek maak hier ook bloot melding van die talle handboeke vir katk'sasie (154) wat deur Geref prefikante geskryf is asook hulle bydraes in die reeks handboeke oor Bybelkunde en godsdiensonderrig op skool $\left({ }^{155}\right)$.

Ons pastorale studies is pragtig verryk deur die vaardige pen van W. J. de Klerk, wat 'n hele reeks belangrike werke gelewer het, te veel om hier op te noem ( $\left.{ }^{156}\right)$. Ek verwys slegs na Die pastorale gespreksontmoeting ( $\left.{ }^{157}\right)$ ), Kerk en Pastoraat $\left({ }^{158}\right)$, Rousmart $\left({ }^{159}\right)$ en Pastorale Sensitiviteit $\left.{ }^{160}\right)$. C. J. H. Venter bou verder voort on die werk van De Klerk met twee deeglike boeke oor By die sterfbed (161) en Die bediening van die versoening aan die bejaardes ( $\left.{ }^{162}\right)$.

D G. Venter en andere stel 'n Handleiding vir Outerlinge (163) saam en W. J. de Klerk skryf flitsgeragtes oor Die herder-ouderling $\left({ }^{164}\right)$. J. J. van der Walt vind in die Woord van Got die moderne antwoord vir nuwe vrae, ook vir ouderlinge (en diakens) (165). J. P. Jooste besin oor Die roeping tot die amp van predikant ( $\left.{ }^{166}\right)$ terwyl D. G. Venter aantoon dat die vrou in die kerk moet swyg $\left({ }^{167}\right)$. En waar moet ek melding maak van P. J. S. de Klerk se Die gebed in die Heilige Skrif? ${ }^{(168)}$.

Die diakoniek staan op die oomblik in die brandpunt van belangstelling vanweë aandrang om 'n verruimender diakonale taak. Ek verwys hier 0.a. na B. Spoelstra se Nuwe siening ( ${ }^{169} \mathrm{en} \mathrm{K}$. S. van Wyk de Vries se Die scopus van die diakonat $\left({ }^{170}\right)$. In hierdie verband verwys ek ook na die werk van die kulturoloog $\mathrm{C}$. N. Venter vir wie 'n sogenaamde Christelike welsynswerk talle probleme en gevare inhou omdat dit maklik die kerk se barmhartigheidstaak kan verdring of verlam (171). Daar bestaan 'n goeie handleiding vir diakens (172) terwyl W. F. Venter (red) alle belangrike voordragte oor die diakonaat versamel het $\left({ }^{173}\right)$. J. A. Schutte voer 'n warm pleidooi vir 'n funksionele diakonaat wat erns mak met die nood van ons tyd (174). Uiters vermeldenswaardig is ook die studie van die etnoloog $\mathbf{J}$. $\mathrm{H}$. Coetzee oor Die barmhartigheidsdiens van die Gereformeerde Kerk in

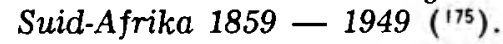

\section{MISSIOLOGIESE ARBEID}

Ek verwys hier eerstens na evangelistiek ('n naam wat trouens al meer vervang word met die naam sending, in die onderskeiding van: sending 1: gerig op heidene, sending 2: gerig op kerkvervreemdes, 
sending 3: gerig op Jode, sending 4: gerig op ander gelowe ens). Op hierdie terrein het ons 'n aantal kleiner geskrifte, bv van W. J. de Klerk ( ${ }^{176}$ ) en P. G. Geertsema (177) asook 'n magdom pamflette en brosjures evangelisasielektuur. Die beoogde publikasie van L. H. Stavast om Redding vir hierdie huis behoort hier 'n welkome toevoeging te wees $\left.{ }^{178}\right)$.

Die groot baanbreker op sendingterrein in die GKSA is sonder twyfel H. du Plessis. Dit is werklik nie oordrewe nie om te stel dat hy die GKSA op hierdie gebied gehelp het om uit sy isolasie te kom en werklik ook sendingkerk te word. Hy het in woord en daad die voorbeeld gestel. Vandat hy in 1959 as professor in Sendingwetenskap aangestel is, het hy hierdie vak pragtig uitgebou. Ek dink aan sy Die missiologie as ' $n$ teologiese wetenskap ( $\left.{ }^{179}\right)$, Geskiedenis van die sendingwetenskap $\left({ }^{180}\right)$ en 'n Banier van die volke $\left({ }^{181}\right)$. Vermelding verdien ook sy strydskrif 'n Nuwe Deurbraak ( ${ }^{182}$ ), wat deur somm'ge - ten onregte - begroet is as „breakthrough to Liberalism” ( ${ }^{183}$ ). Dit was 'n uitstekende gedagte dat 'n aantal oudstudente van sy belangrikste artikels in boekvorm uitgegee het onder die titel Gaan dan heen - $\left({ }^{184}\right)$, bowendien met 'n waarderingswoord en bronnelys. Hier wag 'n pragtige proefskrif vir 'n student in missiologie en die skema lê voor die hand: Hugo du Plessis: as mens, as missionêr, as missioloog, en sy betekenis.

Bogemelde beteken natuurlik geensins dat $\mathrm{H}$. du Plessis die enigste missioloog in die GKSA was nie. Trouens reeds in 1923 het P. J. S. de Klerk die tema van kerk en sending aan die orde gestel ('85). Sendingdeputate laat 'n kort sendinggeskiedenis van die GKSA verskyn ( $\left.{ }^{186}\right)$ ). 'n Hele reeks goeie proefskrifte volg. P. G. Geertsema handel oor sending en sewende gebod $\left({ }^{187}\right)$ I. J. van der Walt oor Eiesoortigheid en die Sending $\left({ }^{188}\right)$, D. C. S. van der Merwe oor verbond en sending $\left({ }^{189}\right)$, J. A. van Rooy oor Language and culture $\left({ }^{190}\right)$, M. A. Kruger oor die vryheidsgedagte ( ${ }^{191}$ ) en M. Venter oor Poliginie as sendingprobleem ( ${ }^{192}$ ). Hierby moet ook nog verwys word na J. A. van Rooy se Kerk en Sending ( $\left.{ }^{193}\right)$ asook D. C. S. van der Merwe se Sending, toekoms en strukture ( $\left.{ }^{194}\right)$ en sy Kerk, volk en ras (195). Baie belangrik vind ek ook die navorsing van L. Floor In dieselfde Spore $\left({ }^{196}\right)$, waarin hy oa die helperamp baie duidelik aan die orde stel, en verder Die Saailand is die Wêreld $\left({ }^{197}\right)$, onder redaksie van Floor uitgegee. Ek sluit af deur te wys op A. G. Schutte se Swart Doppers? ( $\left.{ }^{198}\right)$ en W. Hovy se Bloedgetuies $\left({ }^{199}\right)$.

Samevattend kan ons stel dat daar die afgelope $20-30$ jaar 'n belofteryke ontwikkeling op die gebied van die Sendingwetenskap plaasgevind het en mens kan alleen die hoop uitspreek dat hierdie tendens sal volhou.

Die tema van hierdie artikel verwys na die vraag van ontwikkeling op teoilogiese gebied. Weliswaar is daar ná die Tweede Wêreldoorlog veel méer gepubliseer as daar voor, maar of daar werklik sprake kan wees van - groot - ontwikkeling moet betwyfel word. Daarvoor is te sterk aangesluit by teologiese werke uit die buiteland veral Nederland, en met name Bavinck. Nou is dit natuurlik geen 
skande om in die lyn van Augustinus - Calvyn - Bavinck - Berkouwer teologies voort te werk nie, inteendeel, dit is m.i. nog altyd die beste weg. Tog kan hiermee nie volstaan word nie en moet verder gewerk word op die beproefde pad. Die tyd begin ryp word om 'n „eie" Outestamentologie, Nuwetestamentologie, dogmatiek, etiek en missiologie te skryf. Hierin kan ons bruin en swart teoloë 'n groot bydrae lewer.

Ek sluit af deur daarop te wys dat die bestaan van twee teologiese skole te Potchefstroom en Hammanskraal met 15 professore, die verskyning van die teologiese blad In die Skriflig sedert 1966, die ontstaan en ontwikkeling van die Gereformeerde Teologiese Vereniging sedert 1958 asook die bestaan van die (interkerklike) teologiese werkgemeenskappe in SA, 'n groot stimulus gelewer het vir die ontwikkeling van die teologie in die GKSA in besonder en natuurlik van die teologie in SA in die algemeen. Van groot belang vir die teologie is verder ook die kleiner en groter geskrifte wat uitgegee word deur die Instituut vir die Bevordering van Calvinisme aan die $\mathrm{PU}$ vir $\mathrm{CHO}$.

\section{VOETNOTAS:}

1) In: Eeufees-Gedenkboek. Die Gereformeerde Kerk in Suid-Afrika 1859-1959, Potchefstroom 1959, 138-150. Ek dank ook my Gereformeerde kollegas in die Boland vir hulle kritlese kommentaar.

2) S. J. du Plessis, Jesus en die Kanon van die Ou Testament, T. Wever Franeker/Potchefstroom (1950). Sy studie oor die taal van Prediker kon ek nie betyds opdiep nie.

3) F. N. Lion-Cachet, God, die Here het al hierdie woorde gespreek. Die betekenis van die inleidingsformule van die dekaloog vir die Ou Testamentiese besondere kanoniek, PU vir CHO, Potchefstroom 1976.

4) J. C. Coetzee, Die Blye Boodskap. 'n Gids deur die boeke van die Nuwe Testament. 1. Die Briewe van Paulus, Pro Rege, Potchefstroom 1975.

5) J. C. Coetzee, 'n Pleidooi vir vernuwing in die Besondere Kanoniek toegelig aan die hand van die evangelie van Johannes, PU vir CHO, Potche:stroom 1976.

6) H. F. van Rooy, 'n Vergelyking van die struktuur van die buite-Bybelse staatsverdrae - met besondere aandag aan die Sefire-verdrae met die struktuur van Deuteronomium, PU vir CHO, Potchefstroom 1977.

7) J. Postma, Die hyperbaton in die Pauliniese en Hebreërbriewe en sy betekenis ook vir die vertaling, UP, Pretoria 1963.

8) H. S. Pelser, Rabbula, die biskop van Edessa, PU vir CHO, Potchefstroom/ Pretoria 1967; S. J. Smit, Die ondergang van die ryk van Juda, Groningen (1965).

9) S. du Toit, Ou Testament en Ou Ooste. 'n Bybels-argeologiese studie. Pro Rege Pers, Potchefstroom 1971. J. A. LOADER vind die boek egter te breed opgeset, Die Hervormer, Mei 1972, 30. Vlg. Woord en Daad, Aug 1972, en Gereformeerde Weekblad, 22 Junie 1973. Vgl ook E. J. Smit, Ugarit en Ou Testament. Die betekenis van die ontdekking van die stad Ugarit vir die Ou Testament, PU vir CHO, Potchefstroom 1974 
10) S. C. W. Duvenage, Die Dekor van die Nuwe Testament. 'n Kultuur-historiese Agtergrondstudie, Pro Rege, Potchefstroom 1975.

11) P. J. S. de Klerk, Die Brief aan die Hebreërs, J. L. van Schaik, Pretoria 1951.

12) J. H. Kroeze, Het boek Job (Commentaar op het OT), J. H. Kok Kampen 1961.

13) J. H. Kroeze, Het boek Jozua (Commentaar op het OT), J. H. Kok Kampen 1968.

14) J. H. Kroeze, Handboek Bybelse Geskiedenis: Die Ou Testament, Interkerklike Uitgewerstrust, Pretoria/Potchefstroom/Kaapstad 1965.

15) S. du Toit, Openbaringsgeskiedenis van die Ou Testament. Pro Rege Pers, Potchefstroom 1969(4).

16) O.a. ' $n$ Nuwe fase in die stryd om die Ou Testament, Pretoria 1936; Bybelse en Babilonies-Assiriese Spreuke, Christelike Uitgewersmaatskappy, Johannesburg 1942; Die Ou Testament 'n Wonder. Versamelde artikels 19361961. Pro Rege Pers, Potchefstroom 1963; Bybel Skepping-Evolusie, Voortrekkerpers 1968(2).

17) J. L. Helberg, Openbaringsgeskiedenis van die OT, Pro Rege, Potchefstroom 1976.

18) J. L. Helberg, Die val van Jerusalem en die dag van Jahwe, PU vir CHO, Potchefstroom 1965; Ou Testamentiese teologie in verleentheid? Twee studies oor uitgangspunt en metode, PU vir CHO, Potchefstroom 1976.

19) P. J. S. de Klerk, Woorde en Dade van die profete, Van Schaik, Pretoria 1953.

20) J. H. Kroeze, Psalm 47, Den Haag NV 1966 (Exegetica 4:6).

21) F. N. Lion Cachet, Die kontinuiteit van die Abrahamitiese verbond in die opset van die Sinaitiese verbond, PU vir CHO, Potchefstroom 1977.

22) W. J. Snyman, Nuwe en Ou Dinge. Uit die Skat van die Kaninkryk, Pro Rege, Potchefstroom 1977.

23) T. van der Walt, Die Koninkryk van God - Naby! Eksegetiese verkennings van die toekomsperspektief van Jesus Christus volgens die getuienis van die Sinoptiese Evangelies, J. H. Kok NV Kampen 1962.

24) Tjaart van der Walt, Openbaringsgeskiedenis van die Nuwe Testament. 'n Gids vir Bybelkundestudente ( $A B C$ ), Pro Rege, Potchefstroom 1973. Dieselfde materiaal is ook min of meer terug te vind in Openbaringsgeskiedenis Die Nuwe Testament Standerd 7 en 8 , Interkerklike Uitgewerstrust, Pretoria 1972 (7-104).

25) J. C. Coetzee, Volk en Godsvolk in die Nuwe Testament. 'n Eksegetiese studie, Pro Rege Pers, Potchefstroom 1965.

26) L. Floor, De nieuwe exodus. Representatie en inkorporatie in het Nieu. we Testament, PU vir CHO, Potchefstroom 1969.

27) L. Floor, Die Konin'sryk van God en die Vernuwing van die Maatskappy, Pro Rege Potchefstroom (1974); Persone rondom Paulus, NG Kerkboekhandel, Pretoria 1978.

28) J. A. Schutte, Die titel Kyrios by Paulus as aanduiding van Jesus, Pretoria 1951.

29) W. J. van der Merwe, Die terminologie van liefde in die Nuwe Testament - 'n eksegetiese studie, $\mathrm{PU}$ vir CHO, Potchefstroom/Vereeniging 1953.

30) P. J. S. de Klerk, Woorde en Dade van Jesus, J. L. van Schaik, Pretoria 
1951. In hierdie werk word baie sterk - selfs woordeliks - aangesluit by J. H. Bavinck se Geschiedenis der Godsopenbaring. Het Nieuwe Testament, Kok Kampen 1955 (3).

31) S. du Toit, e.a. Die Koninkryk van God, Potchefstroom 1969.

32) Vgl. C. J. H. de Wet, Die Kollegiale Kerkreg, H. A. van Buitenburg, Amsterdam 1921.

33) G. P. L. van der Linde, Die Grondbeginsels van die Presbiteriale Kerkregeringstelsel, Pro Rege Pers, Potchefstroom 1965.

34) Vgl. Die Kerkblad 4 Mei 1966 (krities), Die Hervormer Junie 1966, (waarderend),) In die Skriflig 5/6 1967 en veral Gereformeeerd Theologisch Tydschrift Nov. 1966 ("weinig originaliteit", "geen nieuwe gezichtspunten").

35) J. J. van der Walt, Christus as Hoof van die Kerk en die Presbiteriale Kerkregering, Pro Rege, Potchefstroom 1976.

36) B. Spoelstra e.a. Handleiding by die Kerkarde van die Gereformeerde Kerk in Suid-Afrika, Pro Rege Pers, Potchefstroom 1966.

37) Vgl. ook J. P. Jooste se Diktaat Gereformeerde kerkreg en diktaat kerklike administrasie en organisasie, Pro Rege, Potchefstroom 1955.

38) Bv. die wyse waarop die reduksie van art. $61 \mathrm{~K} 0$ deur die Nasionale Sinode GKSA van 1964 verdedig word (AW 373v). Vgl. my art. Comminio/en Admissio in: In die Skriflig, Junie 1978 (40-47).

39) Vlg. L. S. Kruger, Die praktiese toepassing van die kerklike tug. Pro Rege, Potchefstroom 1958.

40) Vgl. J. V. Coetzee, Geskiedenisversaking. Revisie van 'n "gekorrigeerde" brosjure van prof. dr. S.P. Engelbrecht, Calvyn Jubileum Boekefonds, Potchefstroom (1946).

41) O.a. in Gedenkalbum Eeufees Die Gereformeerde Kerk Burgersdorp 18601960, Burgersdorp 1960.

42) J. P. Jooste, Die Verhouding tussen Kerk en Staat aan die Kaap tot die helfte van die 19e Eeu, Sacum, Bloemfontein 1946.

43) J. P. Jooste, Die Geskiedenis van die Gereformeerde Kerk in Suid-Afrika 1859-1959, Potchefstroom (1958).

44) J. P. Jooste, Gedenkboek van die Dorslandtrek, Potchefstroom (1974). Vgl. bl. 128 waar vermeld word van 'n beswaar dat 'n predikant van blankes nie die reg het om Woord en Sakramente aan nie-blankes te bedien nie! Is dit dalk een van die redes waarom die Marxiste vandag in Angola regeer?

45) G. C. P. van der Vyver, Professor Dirk Postma 1818-1890, Pro Rege Pers, Potchefstroom 1958.

46) G. C. P. van der Vyver, My erfenis is vir my mooi. Calvyn Jubileum Boekefonds, Potchefstroom 1969. Vgl ook J. P. Jooste se Die Geskiedenis van die $\mathrm{PU}$ vir $\mathrm{CHO}$ (tot inkorporasie), Potchefstroom (1957). Voorts G. C. P. van der Vyver, God en mens in die kerkgeskiedskrywing, PU vir CHO, Potchefstroom 1976.

47) B. Spoelstra, Die "Doppers" in Suid-Afrika 1760-1899. Nasionale Boekhandel, Kaapstad 1963.

48) B. R. Krüger, Die Ontstaan van die Gereformeerde Kerk in Suid-Afrika, V \& R Drukkery, Pretoria 1957. Vgl ook sy Die Ontstaan, Ontwikkeling en Betekenis van die Gereformeerde Kerk op die Witwatersrand, Craft Drukpers, Pretoria (1956). Die laaste hoofstuk van lg. werk handel oor "Die 
Gereformeerde Kerk as bolwerk van die Afrikanerdom op die Witwatersrand".

49) Deur J. C. H. R. Coetzee in Eeufees-Gedenkboek Die Gereformeerde Kerk in Suid-Afrika 1859-1959 a w 144.

50) Aw soos (1).

51) P. J. S. de Klerk e.a. Eeufees te Rustenburg, $\mathrm{PH}$ Drukkery, Potchefstroom 1959.

52) Ek verwys slegs na die volgende: Eeufeesgedenkalbum Klassis Waterberg 1859-1959, Potgietersrus s.j.; Eeufeesgedenkboek Gereformeerde Kerk Colesberg KP 1860-1960, Potchefstroom (1961); Eeufees-Gedenkboek van die Gereformeerde Kerk Bethulie 1863-1963, Bethulie (1963); Eeufees-Gedenkboek Gereformeerde Kerk Dordrecht KP 1869-1969, Dordrecht 1969; Gereformeerde Kerk Steynsburg 1872-1972 s.u. en s.j. Gereformeerde Kerk Venterstad. Eeufeesalbum 1875-1975 s.u. en s.j. Vgl ook Gedenkalbum van die Gereformeerde Kerk in Suid Rhodesië 1914-1964, Salisbury 1964.

53) M. J. Badenhorst, Die Kruiskerk en die Strydenburgse kerkkwessie, met di S. J. du Toit en Andrew Murray in twee kampe, T. Wever, Stellenbosch (1975).

54) V. E. d'Assonville, Tatius - Profeet van die Mooirivier. 'n Lewenskets van prof. dr. J. D. du Toit, Tafelberg 1977.

55) B. Duvenage, Die Religieuse Grondmotief van die konsepsies van Visser't Hooft met betrekking tot die Wereldraad van Kerke, Boekhandel De Jong, Braamfontein $1971 \mathrm{vgl}$. ook sy Calvyn en die ekumeniese roeping van die kerk, PU vir CHO, Potchefstroom 1975. Baie krities oor die sogenaamde teologie van die WRK was ook S. J. van der Walt in sy inougurele rede. Meer genuanseerd oordeel W. J. Snyman, Nuwe en Ou dinge aw 85,86.

56) J. M. Vorster, Die Kerk en die Kleurvraagstuk vandag. Die hantering van die kleurvraagstuk deur die Wêreldraad van Kerke en die Gereformeerde Kerke in Nederland teen die agtergrond van die kontemporêre kultuur, PU vir CHO, Potche'stroom 1977.

57) P. J. Pelser, Die roeping tot sigbaarmaking van die katolisiteit van die kerk, PU vir CHO, Potchefstroom 1976.

58) P. J. S. de Klerk, Gereformeerde Simboliek, J. L. van Schaik, Pretoria 1954.

59) B. J. van der Walt, Die natuurlike teologie met besondere aandag aan die visie daarop by Thomas van Aquino, Johannes Calvyn en die Synopsis Purioris Theologie; ' $n$ wysgerige ondersoek, PU vir CHO, Potchefstroom 1974. Vir 'n kritiese bespreking hiervan vgl. Ned. Geref Teologiese Tydskrif, Maart 1976 asook In die Skriflig, Mrt 1977.

60) C. J. Malan, Ambrosius as oorgangsfiguur tussen die klassieke kultuurpatroon en sekere aspekte van die vroeë Christendom, PU vir CHO, Potchefstroom 1976.

61) J. M. de Wet, Grondtendense van die Kreatief ewolusionistiese Wysbegeerte, 1941 .

62) P. J. Coetzee, Die Antropologie van die Vroegmoderne Humanisme, 1949.

63) L. S. van der Walt ea, Waarheid en Dwaling. Weerlegging van die dwalinge van die vernaamste sektes en strominge in ons land, Adm. Buro, Potchefstroom (1945).

64) B. J. de Klerk, Tendense in die moderne wysbegeerte en teologie, vanuit ' $n$ apologetiese standpunt, Potchefstroom (1952). 
65) B. J. de Klerk, Die Roomse Gevaar, Holl Afrik Uitg My, Pretoria/Kaapstad 1952.

66) S. P. van der Walt, Die Wysbegeerte van Dr. Herman Bavinck, Pro Rege Pers, Potchefstroom 1953.

67) Vgl. R. H. Bremmer, Herman Bavinc'r als dogmaticus, J. H. Kok NV Kampen 1961, 5: „Van der Walt gaf een verdienstelijk overzicht van Bavincks wijsbegeerte in samenhang met die van Kuyper en Woltjer".

68) S. P. van der Walt, Gereformeerde Apologetiek, sy taak en terrein, Potchefstroom (1955).

69) S. P. van der Walt, Dwaling en Waarheid. Oor sektes en godsdienstige strominge, Pro Rege Pers, Potchefstroom 1961. Vgl. ook sy Morele Herbewaping, PU vir CHO, Potchefstroom s.j.

70) D. Kemp'f, Rotary - ' $n$ kritiese bespreking oor die Rotariërbeweging, Pro Rege, Potchefstroom 1963.

71) D. Kempff, Geloofsgenesing en tongetaal getoets, Pro Rege, Potchefstroom 1974. Meer positief - en Bybels - oordeel Cassie Venter, Geestesgawes: wat se die Bybel? Potchefstroom s.j.

72) L. S. Kruger, Die Apostoliese Geloofsending van Suid-Afrika: 'n Kerk of 'n Sekte? Potchefstroom s.j.

73) L. S. Kruger, Waarom is $u$ lid van Die Gereformeerde Kerk? Pretoria (1956).

74) W. J. de Klerk ea, Roeping en Werkli'heid, Potchefstroom Herald, Potchefstroom 1972.

75) L. Floor, e.d. Reformasie en Revolusie, IBC, PU vir CHO, Potchefstroom 1974.

76) S. C. W. Duvenage, e.a., Die Atoomeeu - in $U$ lig. IBC, PU vir CHO, Potchefstroom 1969.

77) Vgl. o.a. H. G. Stoker, Praktiese Calvinisme, Pro Rege Pers, Potchefstroom 1956; Beginsels en Metodes in die Wetenskap, Pro Rege Pers, Potchefstroom 1961; Oorsprong en Rigting Band I, Tafelberg-Uitg, Kaapstad 1967 asook Band II, 1970. Sien ook V. Brümmer e.a., Waarheid en Werklikheid. Wysgerige perspektiewe op die werklikheid. Opgedra aan Professor H. G. Stoker, Boekhandel De Jong, Braamfontein 1971.

78) Vgl. o.a. J. A. L. Taljaard, Polished Lensis. A philosophy that proclaims the sovereignty of God over creation and also over every aspect of human activity, Pro Rege Press, Potchefstroom 1976 en J. A. Kruger e.a. Social activity \& Practice. Crosscuts and Perspectives. Philosophical Essays in Homour of Prof. J. A. L. Taljaard, PU vir CHO, Potchefstroom 1975.

79) Klaus Nürnberger, Sistematiese Teologie, Genadendal 1975.

80) J. V. Coetzee ea, Kosbare Goud, Gereformeerde Geloofsleer, Nasionale Pers, Kaapstad 1942, Vgl. ook J. V. Coetzee, Neo Calvinisme - verbastering of regte ontwikkeling? Calvyn Jubileum Boekefonds, Potchefstroom (1943).

81) Vgl. S. J. van der Walt in: Geloofsleer en Sedeleer vir standerd 10. Handboek vir die Onderwyser, Interkerklike Uitgewerstrust, Pretoria s.j. Vgl. ook sy Die mens of God? Môrester Drukkery, Potgietersrus (1956).

82) A. Duvenage, Institusie of Onderwysing in die Christelike gadsdiens (van Jean Calvin 1509 - 1564) (vertaal en verkort), Pro Rege, Potche:stroom 1967. Ek meld hier ook D. Kempff se A. bibliography of Calviniana, 1959 
- 1974, IAC, Potchefstroom 1975.

83) V. E. d'Assonville, John Knox and the Institutes of Calvin; a few points of contact in their theology, Drakensberg Press, Durban 1968.

84) Vgl. J. D. du Toit, Versamelde werke van Totius $(1-11)$, Tafelberg, Kaapstad 1977 en Versamelde wer'ce van J. D. du Toit (Totius) $(1-8)$, Dagbreek, Johannesburg 1960 - 62.

85) Ook H. Berkhof is vol lof vir die dogmatiek van Bavinck en noem dit 'n werk „die zich hoog verheft boven vele vergelijkbare werken in binnenen buitenland... Dat werk, vol met informatie en inzicht, bovendien in fraaie stijl geschreven, is tot op heden voor de dogmaticus een Fundgrube" (Christelijk Geloof. Een inleiding tot de geloofsleer, G. F. Callenbach B. van Nijkerk 1973. XVI).

86) I. D. Krüger, God se Voorsienigheid, Pro Ecclesia-Boekhandel, Stellenbosch 1946. F. van der Walt is tans besig met 'n proefskrif van die Godsleer van Molytmann.

87) D. Kempff, Die skeppingsleer van Karl Barth, HAUM, Amsterdam 1949.

88) Vgl. N. G. S. van der Walt, Die ape-weg na koningskap, Die Evangelis, Potche'stroom 1964; M. J. Booyens, Ewolusionisme. 'n Antichristeli'se denksisteem, Potchefestroom (1970).

89) K. S. van Wyk de Vries, Die realiteit van die koninkryk van God, PU vir CHO, Potchefstroom s.j.

90) S. C. W. Duvenage, Die Navolging van Christus, Pro Rege Pers, Potchefstroom 1954.

91) C. J. Malan, Soteriologie by Calvyn, PU vir CHO, Potchefstroom 1977.

92) L. F. Schulze, Calvin's reply to Pighius, Pro Rege Press, Potchefstroom 1971.

93) G. C. P. van der Vyver e.a., "Revival" of Reformasie? 'n Studie oor Metodisme, PU vir CHO, Potchef stroom 1975.

94) P. J. Coetzee, Uitverkiesing en bekering, PU vir CHO, Potchefstroom 1976.

95) C. Hattingh, Die kerk en die Heilige Gees, Die Evangelis, Potchefstroom sj.

96) P. J. S. de Klerk, Kerk en Verbond, Pro-Ecclesia Drukkery, Stellenbosch 1943; Belofte en eis van die genadeverbond, Westelike Stem, Potchefstroom (1949); Vgl. ook sy Die Genadeverbond, Nas Pers, Bloemfontein (1929).

97) P. W. Buys, Die ekklesiologiese onders'ieiding organisme en instituut as antwoord op die problematiek van die volkskerk; 'n historiese, prinsipiële en praktiese studie, PU vir CHO, Potchefstroom 1970.

98) S. C. W. Duvenage, Die Verhouding van Kerk tot Volk, T. Heijnis Tsz, Zaandijk 1962.

99) B. J. de Klerk, Vorme en karakter van die Biblisisme, Kampen (1937).

100) S. J. van der Walt, Die Godsopenbaring in die teologie van Karl Barth, Stellenbosch 1941.

101) J. D. du Toit, Die Bybel is die Woord van God, Pro-Ecclesia-drukkery, Stellenbosch 1941.

102) S. C. W. Duvenage, Die Gesag van die Heilige Skrif, IBC, PU vir CHO, Potchefstroom (1967).

103) Vgl. sy Versamelde Werke VIII, Johannesburg 1962 a.w., 15: „Mag ons hierdie (Dogmatische) Studiën (van prof. dr. G. C. Berkouwer), wat 'n hele reeks sal vorm, baie warm by ons teoloë en ander belangstellendes aanbeveel. Hier is dan nou dogmatiek in sy volle aktualiteit, dogmatiek wat 'n 
mens laat tintel van belangstelling om voort te gaan" (1949).

104) C. F. C. Coetzee, Die scopus van die Skrif by Calvyn: 'n dogmatiese verkenning van sekere hoofstukke uit die Institusie van Calvyn, $\mathrm{PU}$ vir $\mathrm{CHO}$, Potchefstroom 1972. Vgl. ook sy Calvyn en die Skrif, PU vir CHO, Potchefstroom 1973.

105) F. W. Buytendach, Aspekte van die vorm/inhoud-problematiek met betrekking tot die organiese Skrifinspirasie in die nuwere gereformeerde teologie in Nederland, Ton Bolland, Amsterdam 1972.

106) H. Denkema, Die betroubare Woord. ' $n$ Ondersoe! na die aard van die Skrifgesag, Unisa 1973. Opvallend is ook die titel „betroubare” Woord i.p.v. "onfeilbare" Woord.

107) Vgl. sy M-studie en sy artikel in Die koninkryk van God aw. 185-214. Ook $P$. J. Coetzee het hier 'n bydrae gelewer, vgl. sy twee artikels in In die Skriflig, Des. 1970 en Junie 1977. Vgl ook J. H. van Wyk in In die Skriflig, Des. 1974.

108) J. W. Jansen van Ryssen, Die Messias uit die aarde. 'n Populêre verhandeling oor die Antichris, Pro Rege Pers, Potchefstroom 1956 (2). Vgl. ook D. G. Venter, Eindbestemming van die Skepping, Evangelis Potchefstroom 1964 .

109) Vgl. o.a., A. König, Jesus Christus die Eschatos. Die fundering en struk. tuur van die eskatologie as telogiese Christologie, N.G. Kerkboekhandel, Pretoria 1970, 414 v, Een wat sterker is, N.G. Kerkboekhandel, Pretoria 1971, 93v; Kyk, Ek kom gou, N.G. Kerkuitgewers 1974, 125v.

110) T. van der Walt in: Die Koninkryk van God, Potchefstroom 1969, Insgelyks in Gereformeerde Kerk Steynsburg 1972-1972, 72 en Die Kerkblad, 13 Sept. 9.

111) C. W. M. du Toit, Toekomstige Wereldgebeure, Christelike Uitgewersmaatskappy, Roodepoort (1948). Vgl. ook P. J. de Bruyn, Dood en Opstanding, Pro Rege Pers, Potchefstroom 1972.

112) Vanweë die groot gebrek aan etiese werke noem ek hier opsetlik 'n aantal artikels: B. Duvenage, o.a. Die positivering van die etiese norm in: Koers, Aug. 1968 ( $5-20)$; Is die Nuwe Moraal rewolusioner? in: Bulletin van die Suid-Afrikaanse Vereniging vir die Bevordering van Christelike Wetenskap (SAVBCW), Sept. 1968 (191 - 197); Veranderende norme in: Besinning en Uitsig. Potchefstroom 1969; Sekularisasie (resp sekularisme) in die sedelike (teorie en praktyk), in: Bulletin SAVBCW, Okt. 1970 (5-18); Permissiviteit en die beoordeling van sedelike vraagstuk'se, in: Almanak GKSA 1972 (171 - 177). Spesi ieke probleme is aangesny in sy Abortus provocatus vanuit etiese gesigspunt in: Bulletin SAVBCW, Okt. 1971 (14 33) en Die etiese aspekte van bevolkingsontplaffing in: Reformasie en Revolusie aw (295 - 308).

113) B. Duvenage, Beroepsarbeid in die lig van die Gereformeerde Etiek, PU vir CHO s.j.

114) S. P. van der Walt, Gods wet en "die ander wet", Potchefstroom s.j. In latere jare het Van der Walt al meer gekonsentreer op etiese vraagstukke. Ek dink o.a. aan sy Die nuwe moraal in: In die Skriflig, Okt. 1966 (4-10); Revolusie in die etiek in: Reformasie en Revolusie aw $(79-90)$ en Etiek - wetenskap van relasies in: Waarheid en Werkli'iheid aw (222 - 233).

115) P. W. Buys, Die botsing van pligte as etiese vraagstuk, PU vir CHO, Potchefstroom 1976. Vgl. ook sy Homofilie in: In die Skriflig, Maart 1976 (15 
- 21) en 'n Paar gedagtes oor ' $n$ Calvinistiese kunsetiek met besondere veruysing na die probleem van pornografie en perssensuur. IBC-Studiestuk nr. 94, Aug. 1975, Potche'stroom.

116) H. G. Stoker, Die Grond van die Sedelike, Pro Ecclesia-Drukkery, Stellenbosch 1941.

117) P. G. W. du Plessis, Opskorting van die etiese? Die ontwerp van die etiese behore by $M$. Heidegger, K. Jaspers, J. P. Sartre en $S$. de Beauvior, Pro Rege Pers, Potchefstroom 1965.

118) P. J. de Bruyn, Bewaar jou goeie pand. Vraagstukke besien vanuit Gereformeerde standpunt, Pro Rege Pers, Potchefstroom 1964. Vgl. ook sy God se Tien ba'iens vir die lewe van die mens, Pro Rege Pers, Potchefstroom 1976 (2).

119) J. H. van Wyk, Etiek in 'n eeu van tegnologie en tegnokrasie, PU vir CHO, Potchefstroom/Johannesburg 1971.

120) J. W. Jansen van Ryssen e.a. Die Selfmoord van ' $n$ nasie. Geboortebeperking: sy oorsake en gevolge, HAUM, Kaapstad 1944.

121) S. J. van der Walt (red), Die heilige huwelik, HAUM Kaapstad/ J. H. de Bussy Pretoria 1952.

122) J. H. Kroeze, Bybel en Seks, Boekhandel De Jong, Braamfontein 1970.

123) P. J. de Bruyn, Die Christen en Geboortereèling. Pro Rege, Potche:stroom s.j.

124) Vgl. J. H. van Wyk, Etiek in eeu van tegnologie en tegnokrasie a.w. 74v.

125) P. J. de Bruyn, Kuisheid voor die huwelik, Pro Rege Pers, Potchefstroom 1971. Vgl. ook sy Die Christen en kleredrag, Pro Rege Potchefstroom 1975 (4).

126) P. J. de Bruyn, Die plek van die mens in die etiek van $H$. M. Kuitert. 'n Kritiese bespreking van sy etiek teen die agtergrond van sy vemaamste .dogmatiese beskouings, PU vir CHO, Potchefstroom 1977.

127) J. H. van Wyk, Etiek van Vrede. 'n Teologiese etiese evaluering van Christenpasifisme, Potchefstroom 1974.

128) Vgl. a.o. Vrede onder bedreiging van oorlog in: Reformasie en Revolusie a.w. (99-118); Etiek en Ekologie, in: Bulletin SAVBCW, Febr. 1974 (38 49); Etiek en Demografie, in: Bulletin SAVBCW, Maart 1975 (19-29); Etiese beginsels en ekonomiese feite in: Bulletin $S A V B C W$, Sept. - Des. 1976 ( 40 - 57); Die Etiek van Dans, IBC-Studiestuk nr. 97, Nov. 1975, Potchefstroom; Suicidologie. 'n Etiese en pastorale gesprek oor selfmoord, IBC-Studiestuk nr. 89, Maart 1975; Etiek en Eskatologie, in: Ned. Geref. Teologiese Tydskrif, Junie 1975 (212 - 226).

129) Ek verwys slegs na die volgende: J. D. en S. du Toit, Die Afrikaanse Rassebeleid en die Skrif, Potchefstroom, 1955 (2); S. du Toit, Holy Scripture and Race Relations, Potchefstroom 1960; L. J. du Plessis, Apartheid, Ja of nee of ja-nee?, Potchefstroom 1957; Uit een bloed, Potchefstroom 1961, Hugo du Plessis, 'n Nuwe Deurbraak, Potcheistroom 1963; Republiek en Koninkryk, Potchefstroom 1964; W. J. Snyman e.a. 'n Lig vir die volke, Potchefstroom 1969; B. Spoelstra, Die Bybel en ons Afrikaanse Volkebeleid, Pretoria 1970; J. H. Coetzee, Blanke Volksontwikkeling in die lig van die Calvinisme, Potchefstroom s.j. idem, Volk(?) sonder land? Potchefstroom 1971; idem, Die Calvinisme en Volkereverhoudinge (IBC-Studiestuk no. 46), Potchefstroom s.j. W. J. de Klerk, Afrikanerden'ce. Kontoere van 'n standpunt, Potchefstroom 1971. Baie belangrik is ook P. J. J. S. Potgieter se 
onlangs voltooide Index to literature on the South African Race problem and the policy of separate development (Apartheid).

130) P. G. Snyman, Pers en leser. 'n Prinsipiële voorstudie tot die Persetiek, Pro Rege Pers, Potchefstroom 1971.

131) E. J. G. Norval, Arbeid- 'n prisipiële ondersoek van arbeid met kritiese toespitsing op enkele aktuele hoofprobleme van die Arbeidsetiek, Potchefstroom 1965. Vgl. ook J. D. van der Vyver, Menseregte, Potchefstroom 1974; P. D. van der Walt, Die Calvinis en die Kuns, IBC, Potchefstroom s.j. A. J. van Rooy, Toneel, Film, Radio en Beeldradio vanuit Calvinistiese gesigspunt, IBC, Potchefstroom 1968.

132) W. J. de Klerk, Wending? Vernuwingsgesprekke oor die Gereformeerde kerkpraktyk, Pro Rege Pers, Potche'stroom 1964. Van hierdie boek het sommige geoordeel dat dit hoogs ontydig was.

133) V. E. d'Assonville, Kerk en Prediking, Die Evangelis, Potchefstroom s.j.

134) V. E. d'Assonville, Die dwaasheid om te preek, Boekhandel De Jong, Johannesburg 1976. Eintlik bestaan hierdie boek uit 'n omwerking en uitbouing van Kerk en Prediking en sy artikel Gereformeerde Prediking: Dialekties of apoditis in: In die Skriflig, Sept. 1971 (37-44). Vgl. ook sy Eksistensialisme - 'n vals sleutel vir die prediking, In die Skriflig, Febr. $1967(23-30)$.

135) Ek verwys o.a. na die volgende dagboeke: S. J. van der Walt, Die vaste fondament. Dagboek uit die Heidelbergse Kategismus, Pro Rege Pers, Potchefstroom 1957 (2); J. M. du Plooy (red), My tye in $U$ hand. Oordenkings vir ei':e dag, Pro Rege Pers, Potchefstroom 1961; B. Duvenage (red), Tel die Sterre. Bybelse dagboek oor die Christelike geloofswaarhede, Pro Rege Pers, Potchefstroom 1964; M. J. Booyens, Elke dag in die lig, NG. Kerk Boekhandel Tvl. 1978 (2): M. J. Booyens. Kom Here Jesus!, NG. Kerk Boekhandel Tvl. 1977.

136) Ek verwys ook hier slegs na 'n paar resente preekbundels: J. A. Schutte, Jesus Triomfator, Pro Rege Pers, Potchefstroom 1956, S. P. van der Walt, Wie het ek buiten $U$, Pro Rege Pers, Potchefstroom 1957; P. G. Geertsema, Keer Temug! (Nege preke oor die naggesigte van Sagaria), Pro Rege Pers, Potchefstroom 1958; J. H. Kroeze, Julle eie heil, Pro Rege Pers, Potchefstroom 1960; G. B. S. Pasch, „En uit sy volheid”, Pro Rege Pers, Potchefstroom 1960; I. D. Kruger (en P. A. Verhoef), Vrede op Aarde, Die Evangelis, Potchefstroom 1962; H. J. R. du Plessis, „Die Here is my herder", s.u. (1966); P. G. W. Snyman, Die Here is daar. Preke oor die profesieè van Esegiël (deel 2) en Haggai, Pro Rege Pers, Potchefstroom 1967 (Hierdie bundel volg op Die Hemele geopen. Sacum Bloemfontein s.j. van dieselfde skrywer. In die preke word baie sterk by Veldkamp aangesluit); W. J. de Klerk, Vensters op die hemel, Boekhandel De Jong, Braamfontein 1969; P. J. de Bruyn, Meer werd as sewe seuns. Prelce oor die boek Rut. Pro Rege Potchefstroom 1972; V. E. d'Assonville, Geskeurde Gordyn Potchefstroom 1973; M. J. Booyens (red), Evangelie landswyd, Pro Rege Potchefstroom 1973; H. J. van der Walt (red), Die Rykdom van U Woord, Pro Rege Potchefstroom 1974; J. H. Kroeze, Mos in 'n tros druiwe, T. Wever Stellenbosch 1974; Tjaart van der Walt, God se more begin vandag, Rol op jou move! Pro Rege Potchefstroom 1974; W. J. de Klerk, Onvoltooide wereld, Boekhandel De Jong Johannesburg 1875; J. A. Schutte, Laat my lewe om te loof, De Jong Johannesburg 1976; R. G. Aucamp (red), Die deur van die 
Woord, Pro Rege Potchefstroom s.j. Part Sinode Wes-Tvl, Uit die Woord van God, Pro Rege Potchefstroom 1976; V. E. d'Assonville, Sy koms om middernag. 10 preke uit die Thessalonicense-briewe, Marnix, Potchefstroom 1977; S. J. van der Walt, Maranata. Die Here kom! s.u. (1977) (talle preke verraai 'n sterk konserwatief politiese inslag); J. H. van Wyk (red), Verkondig die Koninkryk, Pro Rege Potchefstroom, 1977; Ben de Klerk

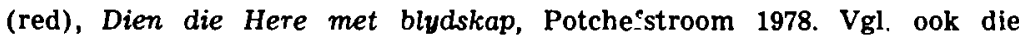
reeks Die lewende Woord in Gereformeerde Kerke gepreek, Pro Rege Potchefstroom s.j.

137 S. C. W. Duvenage, 'n Wereldorde omgekeer. Grepe uit die Bergpredikasie, Pro Rege Pers, Potchefstroom 1967.

138) J. H. Kroeze, Die Hooglied - vir die gemeente verklaar, Pro Rege Pers, Potchefstroom 1953; Koming Hiskia. Teokraat en Reformator, Pro Rege Pers, Potchefstroom 1962; Koning Saul. Die gesalfde van die HERE bevrees vir die manskappe, Pro Rege Pers, Potchefstroom 1962; Die Tuin van Eden. Genesis 2 en 3 aandagtig gelees, NG. Kerk Boekhandel, Pretoria 1967; Die Prediker uit Anatot. Gedagtes en gedigte uit die boek Jeremia, NG. Kerk Boekhandel, Pretoria 1970; Adam en Eva, Boekhandel De Jong 1974; Die woorde van die Prediker, Boekhandel De Jong 1975. Vgl. ook J. H. Kroeze, Die verborgenheid van die geloof, De Jong Johannesburg 1977. So pas het verskyn sy Geveg met God (die boek Job), NG. Kerk boekhandel Pretoria 1978.

139) J. P. Jooste, Kom in sy voorhowe, Adm Buro GKSA, Potchefstroom 1957.

140) P. J. de Bruyn, Aktiewe Kerkgangers, Pro Rege Pers, Potchefstroom 1962.

141) D. C. S. van der Merwe, Twintigste eeuse liturgiese vernuwing: Waarheen? Vorentoe of agteruit? Pro Rege Potchefstroom 1973. Van groot belang ag ek die beplande verkorting van die liturgiese formuliere, reeds in 1971 deur my bepleit (Die Kerkblad, 17 Febr. 1971) deur D. C. S. van der Merwe my verkwalik (Die Kerkblad, 31 Maart 1971) maar deur die Nas. Sinode van 1973 goedgekeur.

142) D. C. S. van der Merwe, Elke Sondag nagmaal? Gewetenssaak vir elke Christen, Pro Rege, Potchefstroom (1974).

143) M. A. Kruger, Wat moet ons sing in godsdiens en erediens? Suid- WesDrukkery, Windhoek s.j.

144) J. J. A. van der Walt, Die Afrikaanse psalmmelodieë, Pro Rege Potchefstroom 1962. Vgl. ook G. Dekker, Die Afrikaanse Psalmberyming, J. L. van Schaik Pretoria 1938.

145) D. Kempff, Erediens en kollekte, Viljoenskroon s.j.

146) Vgl. E. L. J. Venter, Die verband tussen kerk en skool in Suid-Afrika, Amsterdam 1929.

147) C. J. H. de Wet en J. Chr, Coetzee, Die Beginsels, Metode en Geskiedenis van die Kategetiese Onderwys, Nasionale Pers, Kaapstad 1943.

148) J. P. Jooste. Studiegids vir Kategetiek, Pro Rege Pers, Potchefstroom 1965.

149) J. H. van Wyk, Kategetiese Onderrig. Metodiese riglyne, Potchefstroom 1976. Vgl. ook H. J. J. Bingle, Metodiek van Godsdiensonderrig op die Middelbare Skool, Pretoria/Potchefstroom (1962).

150) J. H. van Wyk, Eksistensieteologie en Godsdiensonderrig, Pro Rege Pers, Potchefstroom 1951.

151) S. C. W. Duvenage, Die Opstandinge Student. 'n Analise en evaluering van studenteaktivisme in die VSA., PU vir CHO, Potche istroom 1973. 
152) Vgl. o.a. K. S. van Wyk de Vries e.a. Dink aan jou St.epper, Pro Rege Pers, Potchefstroom 1960; S. J. du Plessis e.a... in die dae van jou jonkheid, Pro Rege Pers, Potchefstroom 1969; J. H. van Wyk e.a., Die wêreld van '70, Korps Veritas Vincet, Potchefstroom 1974; W. Hovy (red), Die lewende iidmaat, Pro Rege Pers, Potchefstroom 1957.

153) P. W. Bingle, Die Gereformeerde Kerk en die onderwys in Suid-Afrika 1859 - 1959, PU vir CHO, Potchefstroom (1959). Vgl. ook sy Die Gerefor. meerde Kerk en die onderwys in Suid-Afrika 1859 - 1899, Potchefstroom 1954.

154) Ek verwys hier o.a. na die volgende handboeke wat by Pro Rege Pers Potchefstroom verskyn het en waarvan die meeste talle herdrukke beleef het: P. J. S. de Klerk Handboek Gewyde Geskiedenis; M. J. Booyens, Laat my lammers wei. Die heilsges'iiedenis vir katkisasie, skool en huis; S. du Toit, Handleiding vir die studie van die Kerkgeskiedenis; B. Spoelstra, Beknopte Kerkgeskiedenis vir Katkisasie; K. S. van Wyk de Vries, Die Leer van ons kerk. Handboek vir gebruik by die kategetiese onderrig; M. J. Booyens, Vir die kerkjeug. Openbaringsgeskiedenis en ons belydenisskrifte vir die Verbondskind; B. Duvenage, Hoofpunte van die Gereformeerde Geloofsleer; W. J. de Klerk en J. H. van Wyk, Woord en Antwoord; P. J. de Bruyn, Die gesonde leer; J. J. van der Walt en G. C. P. van der Vyver, Ken en vertrou. Inleiding tot die boeke van die Bybel en die Dordtse Leerreëls; I. J. Lessing, Bybelse Geskiedenis in Vrae en Antwoorde vir kleiner kinders; M. J. Booyens, Ons glo met die hart en bely met die mond.

155) Hierdie boeke is uitgegee deur die Interkerklike Uitgewerstrust, Pretoria. Ek dink hier o.a. aan die bydrae van S. J. du Plessis, J. L. Helberg, T. van der Walt, J. C. Coetzee, S. C. W. Duvenage, J. H. van Wyk en B. Spoelstra.

156) In sy Pastorale Sensitiwiteit. Fragmente uit die pastorale-psigologie, Perskor Johannesburg 1975 verskyn 'n volledige bronnelys op 111-113.

157) W. J. de Klerk, Die pastorale gespreksontmoeting — 'n prinsipiële studie, PU vir CHO, Potchefstroom 1963.

158) W. J. de Klerk, Kerk en Pastoraat, Die Evangelis, Potchefstroom s.j.

159) W. J. de Klerk, Rousmart. Die pastorale sorg oor beproefdes na die oorlye van ' $n$ dierbare, Boekhandel De Jong, Johannesburg 1968.

160) Vgl. a.w. (156).

161) C. J. H. Venter, By die sterfbed, Pro Rege Potchefstroom 1972. Vgl. ook sy Calvyn en die Herderlike Bediening, PU vir CHO, Potchefstroom 1975.

162) C. J. H. Venter, Die bediening van die versoening aan die bejaarde - 'n pastorale studie in die lig van die pastorale briewe, PU vir CHO, Potchefstroom 1975. Vgl. ook P. J. de Bruyn, Toets my gedagtes. Gesprekke oor die geloofsleue, Pro Rege Pers, Potchefstroom (1965) en sy Twwfel by die gelowige?, Prc Rege Pers, Potchefstroom 1966, en sy 'n Lamp vir my voet. Gesprekke oor die geloofslewe, Pro Rege Potchefstroom 1973. W. J. Maritz, Kyk na die Lelies, Perskor, Johannesburg 1972.

163) D. Gerbrand Venter,Handleiding vir Ouderlinge, Pro Rege Pers, Potchefstroom 1956(2).

164) W. J. de Klerk, Die herder-ouderling; flitsgedagtes, Pro Rege Potchefstroom 1959. Vgl. ook A. Myburgh en C. J. H. Venter (red), So sê die Here HERE. Die Ouderling op Huisbesoek, Pretoria 1977.

165) J. J. van der Walt, Gad se Woord die moderne antwoord, Van Wyk Druk- 
kers (1977).

166) J. P. Jooste, Die roeping tot die amp van predikant, Westelike Stem, Potchefstroom (1950).

167) D. G. Venter, Die vrou in die openbare lewe, Nasionale Pers, Bloemfontein s.j.

168) P. J. S. de Klerk, Die gebed in die Heilige Skrif, Van Schaik, Pretoria 1955 Vgl. ook P J. de Klerk, Tot $U$ bid ek, Pro Rege Pers, Potchefstroom 1967.

169) B. Spoelstra, Is 'n nuwe siening van die diakonale amp op Skrifgronde noodsaaklik? Potch Herald, Potchefstroom 1963. Vgl. ook die artikels in In die Skriflig, Aug. - Sept. 1967 en Feb. - Mrt. 1969.

170) K. S. van Wyk de Vries, Die scopus van die diakonaat, Pretoria 1975.

171) Vgl. o.a. C. N. Venter, Kultuur en versorgingswetenskap. Veldverkenning van die kultuurhistoriese en kenteoretiese grondslae, PU vir CHO, Potchefstroom 1966.

172) J. Postma e.a. Die Diens van Barmhartigheid. Handleiding vir Diakens, Potchefstroom 1959.

173) W. F. Venter (red), Die prys van wat verkoop is. Die diakens vanaf 1935 tot 1975 in Suid Afrika, Pta Drukkers (1975).

174) J. A. Schutte, Want Ek het honger gehad en julle het my nie te ete gegee nie, Pro Rege Potchefstroom (1975).

175) J. H. Coetzee, Die barmhartigheidsdiens van die Gereformeerde Kerk in Suid-Afrika 1859 - 1949, Pro Rege Potchefstroom 1953.

176) W. J. de Klerk, Vader, leer my loop. Gesprekke met verdwaaldes, Pro Rege Potchefsiroom 1961.

177) P. G. Gerrtsema, In Sy Diens. Praktiese handleiding vir evangelisasie be soe'se, Pro Rege Pers, Potchefstroom 1962. Vgl. ook sy The Reformed Church in perspective, Potchefstroom (1969).

178) Tans nog onverskene.

179) H. du Plessis, Die missiologie as teologiese wetenskap, PU vir CHO, Potchefstrooin 1960.

180) H. du Plessis, Geskiedenis van die sendingwetenskap, Pro Rege Potchefstroom 1970 (2).

181) Hugo du Plessis, ' $n$ Banier van die volke. Die Woord van God in en vir die wêreld, Pro Rege Pers, Potchefstroom 1963.

182) H. du Plessis, ' $n$ Nuwe Deurbraak, Pro Rege Pers, Potche:stroom 1963.

183) A. J. G. Oosthuizen in: S.A. Observer, October, 1963 (5).

184) H. du Plessis, Gaan dan heen... 'n Keur uit die geskrifte van wyle prof. H. du Plessis, Sy lewe en werk, Pro Rege Potchefstroom 1976 (met volledige bronnelys 323-328).

185) P. J. S. de Klerk, Kerk en Sending in Suid-Afrika, H. A. van Bottenburg, Amsterdam 1923. Die groot winspunt van die boek is dat dit tereg die genootskaplike sending afwys ten gunste van kerklike sending (145), maar die nadeel is dat die boek te swaar leun op 'n apartheidsteologie $(165-169)$.

186) Sinodale Deputaatskap vir Sending: Die Sending van die Gereformeerde Kerk in Suid-Afrika, Potchefstroom 1953.

187) P. G. Geettsema, Die Christelik-etiese implikasies van die sewende gebod met betrekking tot die sending in Suid-Afrika, Pretoria 1960.

188) I. J. van der Walt, Eiesoortigheid en die Sending. Eiesoortige kerkvorming as missiologiese probleem met besondere verwysing na Suid-Afrika, Pro 
Rege Pers, Potchefstroom 1963. Vgl. ook sy Aspekte van die Afrikanisasie van die kerk gedurende die twintigste eeu, IBC, PU vir CHO, Potchefstroom 1975 (nr. 90).

189) D. C. S. van der Merwe, Die Gereformeerde Verbondsleer in sy betekenis vir die scnding, Potchefstroom 1965.

190) J. A. van Rooy, Language and culture in the communication of the Christian message as illustrated by the Venda Bible, PU vir CHO, Potchefstroom 1971.

191) M. A. Kruger, Vryheid vir die ganse mensheid? Die vryheidsgedagte in die ekumeniese sendingdiskussies, PU vir CHO, Potchefstroom 1973.

192) M. Venter, Poliginie as sendingprobleem, PU vir CHO, Potche:stroom/ Randburg 1975.

193) J. A. van Rooy, Kerk en Sending, Die Evangelis, Potchefstroom s.j.

194) D. C. S. van der Merwe, Sending, toekoms en strukture, Pro Rege Potchefstroom (1973).

195) D. C. S. van der Merwe, Kerk, volk en ras in die sendingbeleid van die Gereformeerde Kerk in Suid-Afrika, Pro Rege Potchefstroom 1973.

196) L. Floor, In dieselfde Spore. 'n Ondersoek na die struktuur van die sendingwerk, Die Evangelis, Potchefstroom (1964).

197) L. Floor (red), Die Saailand is die Wêreld, Hammanskraalse Teologiese Skool van die GKSA s.j.

198) A. G. Schutte, Swart Doppers? Stad, Stamtradisie en Bantoekerk, NGK Boekhandel, Pretoria 1974.

199) W. Hovy, Bloedgetuies van Jesus Christus, Christelike Uitgewersmaatskappy, Roodepoort 1964. 